CZASOPISMO INŻYNIERII LADOWEJ, ŚRODOWISKA I ARCHITEKTURY JOURNAL OF CIVIL ENGINEERING, ENVIRONMENT AND ARCHITECTURE

JCEEA, t. XXXIII, z. 63 (1/I/16), styczeń-marzec 2016, s. 439-446

\author{
Magdalena LASECKA-PLURA ${ }^{1}$
}

Roman LEWANDOWSKI ${ }^{2}$

\title{
ANALIZA DYNAMICZNA KONSTRUKCJI Z TŁUMIKAMI Z NIEDOKŁADNIE OKREŚLONYMI PARAMETRAMI PROJEKTOWYMI
}

\begin{abstract}
W pracy został omówiony sposób obliczania charakterystyk dynamicznych ram z niedokładnie określonymi parametrami projektowymi. Analizowano konstrukcje $\mathrm{Z}$ wbudowanymi pasywnymi tłumikami drgań. Zakłada się, że parametry projektowe mogą się zmieniać, jednak zakres ich zmienności jest znany. Zastosowany rachunek interwałowy pozwala wyrazić parametry projektowe jako tzw. liczby przedziałowe. Przyjęto, że dolna i górna granica szukanych charakterystyk dynamicznych jest przedstawiona jako rozwinięcie w szereg Taylora pierwszego rzędu. W pracy został zamieszczony przykład numeryczny, w którym analizowano ośmiokondygnacyjną, trójprzęsłową ramę z tłumikami. Prezentowana metoda może mieć zastosowanie w praktyce w celu określenia zakresu zmienności charakterystyk dynamicznych przy niedokładnie określonych parametrach projektowych.
\end{abstract}

Słowa kluczowe: charakterystyki dynamiczne, analiza interwałowa, modele tłumików, tłumienie pasywne

\section{Wstęp}

Obecnie coraz częściej powstają konstrukcje, które są projektowane na pełne wykorzystanie parametrów fizycznych i wytrzymałościowych zastosowanych materiałów. Jednak wszystkie parametry projektowe i obciążeniowe obarczone są pewnymi niedokładnościami. Źródła tych odchyleń można podzielić na technologiczne, geometryczne i strukturalne. Te pierwsze są związane z procesami technologicznymi jakim został poddany wyjściowy materiał konstrukcyjny. Do drugiej grupy zalicza się odchylenia od przyjętych wymiarów elementu konstrukcyjnego oraz odchylenia geometryczne związane $\mathrm{z}$ wykonaniem na wytwórni i błędami montażowymi. Ostatnią grupę stanowią nieprawidłowości strukturalne materiałów użytych w konstrukcji.

\footnotetext{
${ }^{1}$ Autor do korespondencji/corresponding author: Magdalena Łasecka-Plura, Politechnika Poznańska, Instytut Konstrukcji Budowlanych, ul. Piotrowo 5, 60-965 Poznań, tel. 61 6652697, e-mail: magdalena.lasecka-plura@ put.poznan.pl

2 Roman Lewandowski, Politechnika Poznańska, Instytut Konstrukcji Budowlanych, ul. Piotrowo 5, 60-965 Poznań, tel. 61 6652472, e-mail: roman.lewandowski@ put.poznan.pl
} 
W procesie projektowania, niedokładności w określaniu parametrów materiałowych i obciążeniowych są uwzględnione w normach projektowych poprzez zastosowanie współczynników korygujących.

Pierwszą grupę metod pozwalających na uwzględnienie niedokładnie określonych parametrów projektowych stanowią metody probabilistyczne, w których te niedokładności w określaniu traktowane są jako wielkości losowe. W praktyce inżynierskiej stosowanie ich jest jednak uciążliwe ze względu na znaczną pracochłonność i trudności w dobraniu właściwego rozkładu losowego. Drugą grupę stanowią metody, w których korzysta się tylko z informacji o zakresie zmienności parametrów.

Do grupy budynków, które wymagają indywidualnego podejścia zaliczają się między innymi konstrukcje wysokie, wrażliwe na drgania, w których stosuje się różnego rodzaju tłumiki drgań. W tej sytuacji dużą trudność sprawiłby właściwy dobór modelu rozkładu losowego parametrów projektowych. Stosunkowo proste jest jednak ustalenie zakresu ich zmienności. W tym przypadku zastosowanie znajduje analiza interwałowa.

Została ona obszernie opisana w pionierskiej monografii Moore'a [6]. Znalazła zastosowanie do rozwiązania wielu zagadnień inżynierskich. W pracy [3] omówiono m.in. możliwości użycia analizy interwałowej do problemów dynamiki. W [1] przedstawione zostało rozwiązanie interwałowego problemu własnego. Rozpatrywano układ bez tłumienia, w którym parametrami o określonej zmienności były masa i sztywność. W pracy [8] przedstawiono sposób zastosowania rachunku interwałowego do analizy modalnej. Analizowano układ bez tłumienia $\mathrm{z}$ niepewnymi parametrami projektowymi, dla którego znaleziono wartości własne, wektory własne oraz funkcję odpowiedzi częstotliwościowej. W pracy [2] została zaproponowana metoda obliczenia wartości własnych wykorzystująca rozwinięcie w szereg Taylora. Wykazano, że metoda daje rezultaty bliskie rozwiązaniu dokładnemu nawet przy założeniu dużych niepewności parametrów projektowych.

W pracy [9] przedstawiono metodę wyznaczenia funkcji odpowiedzi częstotliwościowej układu z niepewnymi parametrami. Natomiast w pracy [4] wyznaczono przemieszczenia wywołane obciążeniami sejsmicznymi i analizowano między innymi budynek z tłumikami pasywnymi.

W niniejszej pracy uwzględniono wpływ niedokładnie określonych parametrów projektowych na częstości drgań swobodnych konstrukcji z tłumikami pasywnymi. Tłumiki są modelowane za pomocą klasycznych modeli Kelvina i Maxwella. Założono, że dolna i górna granica częstości drgań swobodnych jest opisana za pomocą szeregu Taylora. Wyniki obliczeń zostały porównane z wynikami uzyskanymi za pomocą tzw. vertex method, w której uwzględnia się wszystkie możliwe kombinacje górnych i dolnych wartości rozpatrywanych parametrów. 


\section{Podstawy rachunku interwałowego}

Podstawowe założenia rachunku interwałowego zostaną podane na podstawie pracy [6]. Zakłada się, że pewien zbiór parametrów projektowych rozpatrywanego układu zdefiniowany jest jako $\mathbf{p}=\operatorname{col}\left[p_{1}, p_{2}, \ldots, p_{r}\right]$, gdzie $r$ oznacza liczbę parametrów projektowych. Znany jest tylko pewien przedział $\mathrm{w}$ jakim mogą one się zmieniać. Można je zdefiniować jako liczby interwałowe $p_{i}^{I}=\left\lfloor\underline{p}_{i}, \bar{p}_{i}\right\rfloor$, gdzie $\underline{p}_{i}$ oznacza dolną, $\bar{p}_{i}$ górną granicę parametru, a indeks górny $I$ informuje, że wielkość z tym indeksem jest liczbą interwałową. Analiza interwałowa ma na celu znalezienie dolnej i górnej granicy wielkości opisującej zachowanie konstrukcji, która tutaj zostanie opisana jako pewna funkcja $f^{I}\left(p_{i}^{I}\right)=\left[f\left(p_{i}^{I}\right), \bar{f}\left(p_{i}^{I}\right)\right] . \mathrm{W}$ analizie interwałowej definiujemy tzw. wartości centralne parametrów $p_{i}^{C}$ i zakres niepewności parametrów $\Delta p_{i}$ jako:

$$
p_{i}^{C}=\frac{1}{2}\left(\underline{p}_{i}+\bar{p}_{i}\right), \quad \Delta p_{i}=\frac{1}{2}\left(\bar{p}_{i}-\underline{p_{i}}\right)
$$

Podstawowe działania na liczbach interwałowych $x^{I}=[\underline{x}, \bar{x}]$ i $y^{I}=[\underline{y}, \bar{y}]$ definiuje się w następujący sposób:

$$
\begin{aligned}
& x^{I}+y^{I}=[\underline{x}+\underline{y}, \bar{x}+\bar{y}], \quad x^{I}-y^{I}=[\underline{x}-\bar{y}, \bar{x}-\underline{y}] \\
& x^{I} \cdot y^{I}=[\min (\underline{x} \cdot \underline{y}, \underline{x} \cdot \bar{y}, \bar{x} \cdot \underline{y}, \bar{x} \cdot \bar{y}), \max (\underline{x} \cdot \underline{y}, \underline{x} \cdot \bar{y}, \bar{x} \cdot \underline{y}, \bar{x} \cdot \bar{y})] \\
& \frac{x^{I}}{y^{I}}=\frac{[\underline{x}, \bar{x}]}{[\underline{y}, \bar{y}]}=[\underline{x}, \bar{x}] \cdot\left[\frac{1}{\bar{y}}, \frac{1}{\underline{\mathrm{y}}}\right] .
\end{aligned}
$$

W przypadku innych operacji należy zazwyczaj obliczyć wszystkie możliwe kombinacje dolnych i górnych granic i wybrać ich najmniejszą i największą wartość. W porównaniu do tych samych operacji wykonanych na liczbach rzeczywistych rachunek interwałowy wymaga większej liczby działań arytmetycznych. Istotną trudnością jest również możliwość przeszacowania wyniku, którego przedział będzie szerszy niż ten, w którym mogą zawierać się wszystkie możliwe rozwiązania. Mimo tych trudności analiza interwałowa jest przydatnym narzędziem do wyznaczania rozwiązań problemów mechaniki, w których parametry projektowe rozpatrywanych układów są zmienne w pewnych określonych granicach. 


\section{Równanie ruchu ramy z thumikami drgań. Uwzględnienie nie- pewności parametrów projektowych}

$\mathrm{W}$ pracy rozpatrywana jest konstrukcja modelowana jako rama z nieodkształcalnymi ryglami z wbudowanymi tłumikami oraz z masami skupionymi na poziomie stropów. Równanie ruchu takiej konstrukcji można zapisać jako:

$$
\mathbf{M}_{k} \ddot{\mathbf{q}}(t)+\mathbf{C}_{k} \dot{\mathbf{q}}(t)+\mathbf{K}_{k} \mathbf{q}(t)=\mathbf{p}(t)+\mathbf{f}(t)
$$

gdzie $\mathbf{M}_{k}, \mathbf{C}_{k}$ i $\mathbf{K}_{k}$ oznaczają odpowiednio macierze mas, tłumienia i sztywności rozpatrywanej konstrukcji, $\mathbf{q}=\left[q_{1} q_{2} \ldots q_{n}\right]^{T}$ oznacza wektor przemieszczeń konstrukcji, $\mathbf{p}=\left[\begin{array}{lll}p_{1} & p_{2} \ldots p_{n}\end{array}\right]^{T}$ wektor sił wymuszających, $\mathbf{f}=\left[f_{1} f_{2} \ldots f_{n}\right]^{T}$ wektor oddziaływania sił pomiędzy konstrukcją a tłumikami, a $n$ oznacza liczbę stopni swobody dynamicznej konstrukcji.

Po wykonaniu transformacji Laplace'a z zerowymi warunkami początkowymi równanie ruchu (5) można zapisać w postaci:

$$
\left(s^{2} \mathbf{M}_{k}+s \mathbf{C}_{k}+\mathbf{K}_{k}\right) \overline{\mathbf{q}}(s)=\overline{\mathbf{p}}(s)+\overline{\mathbf{f}}(s)
$$

gdzie $\overline{\mathbf{q}}(s)=L[\mathbf{q}(t)], \overline{\mathbf{p}}(s)=L[\mathbf{p}(t)], \overline{\mathbf{f}}(s)=L[\mathbf{f}(t)]$, a $s$ oznacza zmienną Laplace'a. Wektor $\overline{\mathbf{f}}(s)$ zdefiniowany jest jako:

$$
\overline{\mathbf{f}}(s)=-\sum_{i=1}^{r} G_{i}(s) \mathbf{L}_{i} \overline{\mathbf{q}}(s)
$$

gdzie $G_{i}(s)$ zależy od przyjętego modelu tłumika, $\mathbf{L}_{i}$ jest macierzą zależną od położenia tłumika, a $r$ oznacza liczbę tłumików. Rozpatrzono dwa klasyczne modele: Kelvina i Maxwella pokazane na Rys. 1 , gdzie symbole $k_{0}, c_{0}, k_{1}$ i $c_{1}$ oznaczają stałe modeli, $u$ jest siłą w thumiku, a $q_{i}$ i $q_{j}$ to przemieszczenia węzłów tłumika.

a)

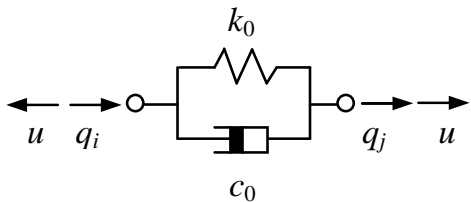

b)

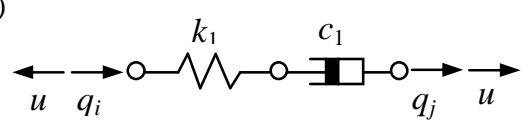

Rys. 1. Modele tłumików a) model Kelvina, b) model Maxwella

Fig. 1. Models of dampers a) Kelvin model, b) Maxwell model

Wielkość $G_{i}(s)$ definiuje się jako $G_{i}(s)=k_{0 i}+c_{0 i} s$ w przypadku modelu Kelvina i $G_{i}(s)=k_{1 i} c_{1 i} s /\left(k_{1 i}+c_{1 i} s\right)$ w przypadku modelu Maxwella.

Równanie ruchu (6) można przepisać w postaci: 


$$
\mathbf{D}(s) \overline{\mathbf{q}}(s)=\overline{\mathbf{p}}(s)
$$

gdzie $\mathbf{D}(s)=s^{2} \mathbf{M}_{k}+s \mathbf{C}_{k}+\mathbf{K}_{k}+\mathbf{G}, \mathbf{G}=\sum_{i=1}^{r} G_{i}(s) \mathbf{L}_{i}$. Jeżeli wektor sił wymuszających jest równy zeru to z (8) otrzymuje się problem własny:

$$
\mathbf{D}(s) \overline{\mathbf{q}}(s)=\mathbf{0}
$$

którego rozwiązaniem jest ciąg zespolonych wartości własnych $s_{j}$ i odpowiadających mu wektorów własnych $\mathbf{q}_{j}$. Jeżeli wartości własne zapisane zostaną w postaci $s_{j}=\mu_{j}+\mathrm{i} \eta_{j}$ to częstości drgań swobodnych można wyznaczyć z zależności $\omega_{j}^{2}=\mu_{j}^{2}+\eta_{j}^{2}$.

Zakładamy, że wybrana charakterystyka dynamiczna konstrukcji jest określona jako funkcja parametrów projektowych $F(\mathbf{p})$. Jeżeli parametry przyjmują wielkości interwałowe, dolną i górną granicę funkcji $F\left(\mathbf{p}^{I}\right)$ można zapisać jako rozwinięcie w szereg Taylora:

$$
\underline{F}\left(\mathbf{p}^{I}\right)=F\left(\mathbf{p}^{C}\right)-\sum_{i}^{m}\left|\frac{\partial F\left(\mathbf{p}^{C}\right)}{\partial p_{i}} \bar{\Delta} p_{i}\right|, \quad \bar{F}\left(\mathbf{p}^{I}\right)=F\left(\mathbf{p}^{C}\right)+\sum_{i}^{m}\left|\frac{\partial F\left(\mathbf{p}^{C}\right)}{\partial p_{i}} \bar{\Delta} p_{i}\right|
$$

gdzie $\bar{\Delta} p_{i}=p_{i}-p_{i}^{C}, \quad \partial F\left(\mathbf{p}^{C}\right) / \partial p_{i}$ jest wrażliwością rozpatrywanej funkcji względem wybranego parametru projektowego $p_{i}$, a $m$ oznacza liczbę parametrów projektowych. Wrażliwości charakterystyk dynamicznych dla ram z tłumikami drgań zostały szczegółowo omówione w pracy [5].

\section{Przykład obliczeniowy}

W przykładzie analizowano ośmiokondygnacyjną, trójprzęsłową ramę z tłumikami Maxwella usytuowanymi na piątej, szóstej i siódmej kondygnacji (Rys. 2). Konstrukcja została zaprojektowana na podstawie EC8 Part 1. Parametry konstrukcyjne, z wyjątkiem masy stropu, zostały przyjęte na podstawie pracy [7]. Wysokość słupów wynosi $3 \mathrm{~m}$, a rozpiętość przęsła $5 \mathrm{~m}$. Moduł Younga $(E)$ dla betonu wynosi $31 \mathrm{GPa}$. Sztywności i wymiary słupów zmieniają się co dwa piętra. Zostały one podane w Tabeli 1 . Masa stropu jest równa $m=60000 \mathrm{~kg} / \mathrm{m}$. Parametry tłumików wynoszą: $k_{1 i}=125000 \mathrm{kN} / \mathrm{m}$ i $c_{1 i}=50000 \mathrm{kNs} / \mathrm{m}$, gdzie indeks $i$ oznacza kolejny numer tłumika. Zostały one przyjęte w ten sposób, aby bezwymiarowy współczynnik tłumienia wynosił $\gamma_{1} \geq 0,04$. Założono, że parametry tłumików mogą zmienić się o $10 \%$ w stosunku do wielkości pierwotnej, więc można je zapisać jako wielkości interwałowe: $k_{1 i}=[112500,137500]$ i $c_{1 i}=[45000,55000]$. Pierwsza częstość drgań swobodnych i bezwymiarowy współczynnik tłumienia dla centralnych wartości parametrów wynoszą $\omega_{1}^{C}=3,4308 \mathrm{rad} / \mathrm{s}$ oraz $\gamma_{1}^{C}=0,0405$. 


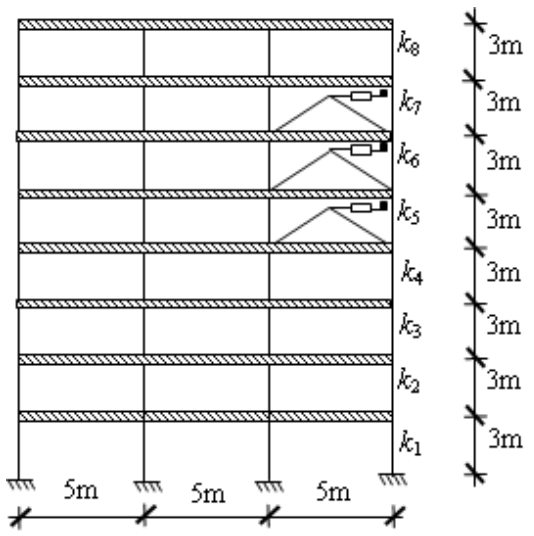

Rys. 2. Schemat rozpatrywanej ramy

Fig. 2. A diagram of the considered frame

Tabela 1. Wymiary słupów i zastępcze sztywności pięter ramy

Table 1. Dimensions of columns and stiffness of stories

\begin{tabular}{|c|c|c|c|}
\hline Kondygnacja & $\begin{array}{c}\text { Zewnętrzne słupy } \\
{[\mathrm{cm}]}\end{array}$ & $\begin{array}{c}\text { Wewnętrzne słupy } \\
{[\mathrm{cm}]}\end{array}$ & $\begin{array}{c}\text { Sztywności pięter } \\
{[\mathrm{kN} / \mathrm{m}]}\end{array}$ \\
\hline 1,2 & $50 \times 50$ & $60 \times 60$ & 441119 \\
\hline 3,4 & $45 \times 45$ & $53 \times 53$ & 275351 \\
\hline 5,6 & $40 \times 40$ & $45 \times 45$ & 152948 \\
\hline 7,8 & $35 \times 35$ & $40 \times 40$ & 93244 \\
\hline
\end{tabular}

Po obliczeniu wrażliwości tych charakterystyk dynamicznych ze względu na zmianę parametrów tłumików, obliczono ich dolną i górną granicę na podstawie zależności (10). Wartości górnej i dolnej granicy po uwzględnieniu zmienności parametrów o $10 \%$ zostały porównane $\mathrm{z}$ wartościami otrzymanymi za pomocą vertex method (patrz. Tab. 2). Przedstawiona metoda wymaga obliczenia tylko $2 m$ kombinacji i jej koszt obliczeniowy jest znacznie mniejszy niż zastosowanie vertex method, wymagającej obliczenia $2^{m}$ kombinacji dolnych i górnych wartości parametrów projektowych. Zarówno w przypadku vertex method jak i przy zastosowaniu metody interwałowej dolna i górna granica została znaleziona dla takiej samej kombinacji parametrów tłumików. Kombinacje te są następujące: $\underline{c}_{11} \underline{c}_{12} \underline{c}_{13} \underline{k}_{11} \underline{k}_{12} \underline{\mathrm{k}}_{13}$ i $\bar{c}_{11} \bar{c}_{12} \bar{c}_{13} \bar{k}_{11} \bar{k}_{12} \overline{\mathrm{k}}_{13}$ dla dolnej i górnej granicy częstości drgań swobodnych oraz $\underline{c}_{11} \underline{c}_{12} \underline{c}_{13} \bar{k}_{11} \bar{k}_{12} \bar{k}_{13}$ i $\bar{c}_{11} \bar{c}_{12} \bar{c}_{13} \underline{k}_{11} \underline{k}_{12} \underline{k}_{13}$ dla dolnej i górnej granicy bezwymiarowego współczynnika tłumienia.

W podobny sposób można obliczyć również inne charakterystyki dynamiczne konstrukcji z niedokładnie określonymi parametrami. Przedstawiony przykład pokazuje, że nawet przy dużych zmianach parametrów projektowych zastosowanie analizy interwałowej z dobrym przybliżeniem pozwala oszacować zakres zmienności funkcji odpowiedzi konstrukcji. 
Tabela 2. Wartości charakterystyk dynamicznych przy zmianie parametrów tłumików

Table 2. Value of dynamic characteristics when dampers' parameters change

\begin{tabular}{|c|c|c|c|}
\cline { 2 - 4 } \multicolumn{1}{c|}{} & Analiza interwałowa & Vertex method & Różnica Błąd \\
\hline Dolna granica $\underline{\omega}$ & $3,4144 \mathrm{rad} / \mathrm{s}$ & 3,4063 & $0,24 \%$ \\
\hline Górna granica $\bar{\omega}$ & $3,4616 \mathrm{rad} / \mathrm{s}$ & 3,4536 & $0,23 \%$ \\
\hline Dolna granica $\underline{\gamma}$ & $0,0334 \mathrm{rad} / \mathrm{s}$ & 0,0337 & $0,89 \%$ \\
\hline Górna granica $\bar{\gamma}$ & $0,0475 \mathrm{rad} / \mathrm{s}$ & 0,0478 & $0,63 \%$ \\
\hline
\end{tabular}

\section{Uwagi końcowe}

W pracy przedstawiono metodę wyznaczania charakterystyk dynamicznych ram z tłumikami drgań, których parametry projektowe są niedokładnie określone. Zastosowano analizę interwałową zakładając, że wartości tych parametrów mogą się zmieniać, a zakres ich zmienności jest znany. Dolna i górna granica wartości funkcji opisującej charakterystyki dynamiczne została rozwinięta w szereg Taylora w otoczeniu wartości centralnych parametrów projektowych. Otrzymane wyniki są bliskie rezultatom obliczonym za pomocą tzw. vertex method. Przedstawiona metoda może mieć zastosowanie w procesie projektowania do oceny zakresu zmienności omawianych w pracy charakterystyk dynamicznych, wynikających z niedokładności w określeniu parametrów projektowych.

\section{Podziękowania}

Badania zostaty sfinansowane czesściowo przez Narodowe Centrum Nauki, jako czesść projektu No. DEC/2013/09/B/ST8/01733 prowadzonego w latach 2014-2016 oraz cześciowo przez Politechnikę Poznańska jako część projektu No. 01/11/DSPB/606.

\section{Literatura}

[1] Chen S.H., Lian H.D., Yang X.W.: Interval eigenvalue analysis for structures with interval parameters, Finite Elements in Analysis and Design, 39, 2003, pp. 419-431.

[2] Chen S.H., Ma L., Meng G.W., Guo R.: An efficient method for evaluating the natural frequencies of structures with uncertain-but-bounded parameters, Computers and Structures, 87, 2009, pp. 582-590.

[3] Dessombz O., Thouveres F., Laine J.P., Jezequel L.: Analysis of mechanical systems using interval computations applied to finite element methods, Journal of Sound and Vibration, 239, 2001, pp. 946-968.

[4] Fujita K., Takewaki I.: An efficient methodology for robustness evaluation by advanced interval analysis using updated second-order Taylor series expansion, Engineering Structures, 33, 2011, pp. 3299-3310.

[5] Lewandowski R., Łasecka-Plura M.: Design sensitivity analysis of structures with viscoelastic dampers, Computers and Structures, 164, 2016, pp. 95-107.

[6] Moore R.E.: Interval analysis, Englewood Cliffs, New York Prentice Hall, 1966. 
[7] Ribakov Y., Agranovich G.: A method for efficient placement of active dampers In seismically excited structures, Structural Control and Health Monitoring, 17, 2010, pp. 513-531.

[8] Sim J.S., Qiu Z., Wang X.: Modal analysis of structures with uncertain-but-bounded parameters via interval analysis, Journal of Sound and Vibration, 303, 2007, pp. 29-45.

[9] Yaowen Y., Zhenhan C., Yu L.: Interval analysis of frequency response functions of structures with uncertain parameters, Mechanics Research Communications, 47, 2013, pp. 24-31.

\title{
DYNAMIC ANALYSIS OF FRAME WITH DAMPERS WITH UNCERTAIN DESIGN PARAMETERS
}

\begin{abstract}
S u m m a r y
In the paper a method for determining dynamic characteristics of frame with uncertain design parameters is described. The structures with built-in passive dampers are considered. The proposed method could be used when the parameters of structures or parameters of dampers are uncertain. The main idea is that values of design parameters could change with respect to values adopted in the design process but the range of their variation is known. The design parameters are expressed as interval values what makes possible calculation of dynamic characteristics of structures by use of interval analysis. In this paper the lower and upper bounds of dynamic characteristics are obtained by use of Taylor series expansion. At the end of the paper a simple numerical example is presented. The eight-storey frame with three bays and three dampers mounted on it is considered. This structure was designed according to EC8 Part 1. The dampers parameters are uncertain. The obtained results are compared with ones determined with a help of the vertex method. This method assumes that it is necessary to calculate end-point combination of uncertain design parameters. The presented method may be applicable in practice in order to predict the limit values of chosen dynamic characteristics of structures with uncertain design parameters.
\end{abstract}

Keywords: dynamic characteristics, interval analysis, models of dampers, passive damping

Przestano do redakcji: 07.06.2016 r.

Przyjęto do druku: 30.06 .2016 r.

DOI: $10.7862 / \mathrm{rb} .2016 .52$ 